Aethiopica. International Journal of Ethiopian and Eritrean Studies welcomes contributions on all aspects of linguistics, philology, history, archeology, palaeography, religion(s), traditional art and culture as well as ethnology (anthropology) related to the Horn of Africa.

Vignette:

Gold coin of King Aphilas, early $3^{\text {rd }}$ century A.D., as drawn by A. Luegmeyer after the coin in Rennau collection. Weight 2.48 grams, diameter $17 \mathrm{~mm}$.

Articles, reviews, conference reports, notes and all correspondence concerning editorial matters should be sent to:

Aethiopica, Abteilung Afrikanistik und Äthiopistik, Universität Hamburg, EdmundSiemers-Allee 1 - Ostflügel, 20146 Hamburg, Germany; Fax: +49 40 42838-5675; e-mail: Aethiopica@uni-hamburg.de.

Contributors are requested to submit their contributions on diskettes and 2 printouts. Additional information can be found at http://www.rrz.uni-hamburg.de/AETHIOPICA.

Only unpublished contributions are accepted for publication. The decision will be made by the editorial management in consultation with the board members.

All views represented in the papers are those of the authors.

Authors will receive 10 free offprints of their contribution.

Subscription orders can be placed with booksellers and agencies or directly with

Harrassowitz Verlag, 65147 Wiesbaden, Germany; Fax: +49 611 530999;

e-mail: verlag@harrassowitz.de.

\title{
Editorial Team:
}

Maija Priess

Thomas Rave

\section{Editorial Board}

David Appleyard, London

Alessandro Bausi, Napoli

Rodolfo Fattovich, Napoli

Marilyn E. Heldman, Silver Spring

Olga Kapeliuk, Jerusalem
Richard Pankhurst, Addis Ababa/London Alain Rouaud, Paris

Shiferaw Bekele, Addis Ababa

Rainer Voigt, Berlin

Publication of this journal was supported by a grant of the Deutsche Forschungsgemeinschaft.

(C) Otto Harrassowitz GmbH \& Co. KG, Wiesbaden 2009

This journal, including all of its parts, is protected by copyright. Any use beyond the limits of copyright law without the permission of the publisher is forbidden and subject to penalty. This applies particularly to reproductions, translations, microfilms and storage and processing in electronic systems.

Printing and binding by Memminger MedienCentrum Druckerei und Verlags-AG

Printed on permanent/durable paper.

Printed in Germany

www.harrassowitz-verlag.de 